\title{
RESPONDING TO LITERARY TEXTS THROUGH POETRY WRITING
}

\author{
Collin Jerome \\ Centre for Language Studies, Universiti Malaysia Sarawak \\ jcollin@cls.unimas.my
}

\begin{abstract}
There are various ways in which readers respond to literature. This article discusses how readers (students in particular) can express their ideas and thoughts about the literary texts they have read through poetry writing. It begins with an overview of reader response theory and the field of literary response research, followed by a discussion of oral and written forms of readers' responses to literature and a classroom activity that requires students to express their thoughts about literary characters in poetic forms. The article also highlights students' proficiency, and literacy and literary skills as some of the factors that need to be considered when using poetry writing as a way of responding to literature.
\end{abstract}

Keywords: reader response theory, literary response research, poetry writing, literary text

\section{Introduction}

There is a substantial body of research that investigates readers' responses to literature. Louis M Rosenblatt (1978), David Bleich (1978), Stanley Fish (1970), Norman Holland and Wolfgang Iser (cited in Tompkins, 1980) are some of the prominent scholars in this field of study. These scholars are the key proponents of the reader response theory that champions readers' subjective rather than objective response to literary texts. ${ }^{1}$ They believe that the reader, the text, and a wide range of factors all play a major role in the process of responding to literature.

There are, as Beach and Hynds (1991) posit, at least three points to consider when one thinks about the process of responding to literary texts:

- Readers can respond to texts in various ways (e.g., symbolic interpretation, asking questions, problem solving)

- Readers can bring different attitudes and values to their reading (e.g., personal attitudes (like/dislike; negative/positive), personal orientations and reasons for reading (self or information-driven))

- Readers' responses are influenced by a variety of factors (e.g., gender, experience, knowledge, curricular, teacher and the environment)

Moss (2003) categorises the different ways in which readers respond to literature into two main types: oral and written forms. Discussion, questioning strategies and dramatic activities make up the oral form of literary response while writing response journal and written retelling of stories are examples of written form of literary response.

Moss's (2003) view is consistent with Bleeker and Bleeker's (1996) claim that students can respond to literature (particularly fiction) through writing poetry. "Poetic forms," as 
Bleeker and Bleeker assert, "provide a framework for students' responses and allow them freedom to respond independently and creatively to a given text" (para. 3). For instance, students can express their understanding of a novel or a play they have read by writing poems. This can be done by allowing students to express their ideas on, for instance, the characters, conflicts, themes, and symbols and write these ideas in a variety of poetic forms (e.g., simple, complex, close, open). Here is an activity that can be carried out with students in a poetry or creative writing class.

1. Divide students into groups of five and ask them to choose one main character in a short story or a novel they have read.

2. Allow students to express their thoughts about the character, particularly the conflict(s) the character experiences and write all these thoughts on a piece of paper.

3. Next, ask students to summarise their thoughts in a short paragraph (by highlighting the key ideas and words) and turn this paragraph into a simple poem.

4. Depending on their level, provide students with a pre-created poem template for organising their ideas and words or give them the freedom to write the poem using a poetic form of their choice. Students may either choose the character's voice or their own to be the voice of the poem.

Text read: Frank O'Connor's My Oedipus Complex

Students' level of proficency: Intermediate to upper-intermediate

Character identified: Larry

Thoughts and ideas about the

Pre-created poem template character's conflict:

Students write about Larry's conflict with his father who has just returned from the war. Students explain how his father's presence has affected his life, particularly his close relationship with his mother. Students also write about the birth of Sonny, Larry's younger brother, who complicates further Larry's relationship with their parents.

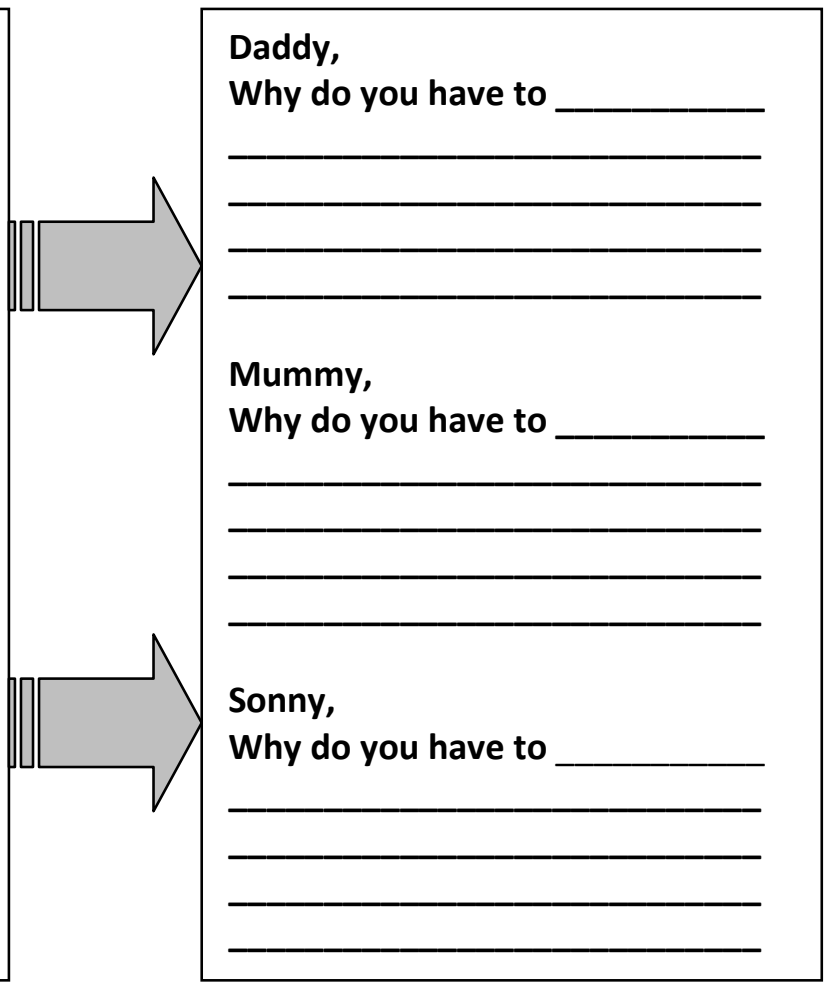


The following are examples of poems that were written based on a creative writing student's response to the main characters (and their conflicts) in lan Worthington's (2004) Alexander the Great: Man and God, William Shakespeare's (1957) The Tragical History of Hamlet Prince of Denmark and Ernest Hemmingway's (1952) Old Man and the Sea and Oscar Wilde's (1992) The Picture of Dorian Gray².

\section{The Great}

Was it because of

Your love for

Hephaestion

That undying

Unswerving

Love

For a fellow brother or

Lover

Were you really

Poisoned or

killed

At the hands of your fellow

Comrades for

Power

Pure jealousy or

Unrequited love

From the great man

\section{Ophelia's Lover}

You are peeling

away

layers upon layers

of mysteries

aching for the answers to

your questions.

You are

awful

in making decision

The rashness

stupidity

clumsiness.

You are

useless

in love

Mother, father die

friends and lover too.

Are you

the royal Dane

or the prince of Death?

Gloom and mysteries

besiege you.

Sadness and paranoia

are your garb

concealing

layers upon layers

of your flaccid existence 
Santiago

It is, they say

an existential battle

between the old man and

the giant fish

amidst the violent sea

under the sunlit sky

It is a battle of the

body and mind they say;

A big catch but

a big loss

The old man wills the battle, but nature refuses to resign

They say that

there are forces

beyond the old man's knowledge and control.

Nature where he comes

And to her he must return.

'So what?' you might ask I say, Can't you see?

\title{
Portrait
}

You are not yourself tonight

your gaze stretches to the far flung horizon

where the evening sun sets in

illuminating the darkening sky

\author{
Unstirred \\ The drowsy breeze \\ pulls down the long silky hair \\ that now blocks your view \\ I seize the moment! \\ on this drawing canvas \\ charcoaling your temperament \\ outlining your fragile beauty \\ charcoal smudging your innocence \\ Here I replicate an image that \\ would cause riots in the hearts \\ of thousands of those who \\ are enchanted by your looks \\ and a thousand more who are \\ envious of your curious charm \\ May this piece of art preserve you \\ your time in space and the moment \\ that captures your callous indifference \\ and your immortal youth \\ But never will it be a reminder of \\ your sins in this world
}

It is important to mention that there are a couple of aspects to consider before allowing students to express their thoughts about the texts they have read through poetry writing.

- Students must have read the said texts and discussed them thoroughly with their instructors

- Students must have a good knowledge of literary elements and devices, and must have adequate exposure to reading and writing poetry

There are also other important factors to be considered including students' proficiency, literacy (e.g. reading and writing) and literary skills (i.e. the ability to read, understand and interpret literary texts), the texts used (e.g., language use, cultural references, content and context) and the subject taught in the classroom (e.g., poetry, creative writing, basic English). But despite all these reservations, it is not impossible to encourage students and readers in general to respond to literature through writing poetry. It would be interesting to see how the above mentioned factors intersect with one another in the process of responding to literature. 


\section{Notes}

1. The proponents of New Criticism such as John Crowe Ransom believe that readers must interpret literary texts objectively and should not bring, for instance, their own experiences and expectations to the whole process. This is because New Criticism "is a literary criticism which concerns itself with the interpretation and evaluation of the 'words on the page' rather than with the study of source and social-cultural background" (Kumar, 2005, p. 24).

2. The poems I have quoted here were written entirely by me when I was a student of an advanced creative writing class at Universiti Putra Malaysia in 2000.

\section{References}

Beach, R., \& Hynds, S. (1991). Research on response to literature. In R. Barr, M. L. Kamil, P. Mosenthal, \& P. D. Pearson (Eds). Handbook of reading research: Volume II (pp. 453489). New York: Longman.

Bleeker, G., \& Bleeker, B. (1996). Responding to young adult fiction through writing poetry: Trying to understand the mole. The Alan Review, 23(3). Retrieved August 24, 2012 from http://scholar.lib.vt.edu/ejournals/ALAN/spring96/bleeker.html.

Bleich, D. (1978). Subjective criticism. Baltimore: John Hopkins University Press.

Fish, S. (1970). The literature in the reader: Affective stylistics. New Literary History, 2(1), 123-162.

Hemmingway, E. (1952). The old man and the sea. New York: Scribner.

Kumar, D. B. (2005). Twentieth century literary criticism. New Delhi: Atlantic Publishers.

Moss, B. (2003). Exploring the literature of fact: Chilren's nonfiction trade books in the elementary classroom. New York: Guildford Press.

Rosenblatt, L. (1978). The reader, the text, the poem: The transactional theory of literary work. United States of America: Southern Illinois University Press.

Shakespeare, W. (1957). The tragical history of Hamlet Prince of Denmark. United States of America: Penguin Books.

Tompkins, P. (1980). Reader-response criticism: From formalism to post-structuralism. Baltimore: John Hopkins University Press.

Wilde, O. (1992). The picture of Dorian Gray. Hertfordshire: Wordsworth Editions Limited.

Worthington, I. (2004). Alexander the Great: Man and God. New York: Longman. 